УДК 801.631.5 : $801.8(=11 /=8): 378.147$

ОКСАНА КАРБАШЕВСЬКА, кандидат філологічних наук, дочент кафедри англійської філології ДВНЗ "Прикарпатський начіональний університет імені Василя Стефаника"

ІРИНА БІЛЯНСБКА, кандидат педагогічних наук, асистент кафедри англійської філології ДВНЗ "Прикарпатський національний університет імені Василя Стефаника"

\title{
ІНТЕРПРЕТАЦІЯ ПОЕТИЧНИХ ТЕКСТІВ ЯК ЗАСІБ РОЗВИТКУ ЛІНГВОСОЦІОКУЛЬТУРНОї КОМПЕТЕНТНОСТІ СТУДЕНТІВ
}

\author{
Oksana KARBASHEVSKA, Candidate of Philological Sciences, As- \\ sociate Professor of English Philology Chair, Vasyl Stefanyk \\ Precarpathian National University \\ Iryna BILIANSKA, Candidate of Pedagogical Sciences, Vasyl \\ Stefanyk Precarpathian National University

\section{INTERPRETATION OF POETIC TEXTS AS A MEANS OF LINGUOSOCIOCULTURAL COMPETENCE DEVEL- OPMENT OF STUDENTS}

\begin{abstract}
У статті представлено загальний зміст елективної навчальної дисципліни "Інтерпретація поетичного тексту". Описано такі теми курсу, як "поезія у колі красних мистецтв", "образність і символізм у поезії, "англо-шотландська фольклорна балада". Зазначено, що художні твори мають високий естетичний, виховний і розвивальний потенціал, а інтерпретація закладеної уних інформації стимулює аналітичне мислення студентів, розвиває їх художньо-естетичне сприйняття, збагачує духовний світ. Зроблено висновок про те, що сформувати лінгвосоціокультурну компетентність студентів можливо засобами тлумачення поетичних творів, оскільки опосередкована міжкультурна комунікація зумовлює розширення кругозору студентів лінгвосоціокультурними знаннями, які є необхідними для досягнення порозуміння у ситуаціях міжкультурного спілкування та розвитку їх здатності до медіації в усній чи письмовій формах. Наголошено, що інтерпретація поетичних творів сприятиме вихованню любові та інтересу до естетики художнього слова, фаху філолога.
\end{abstract}

Ключові слова: поетичний текст, інтерпретація, лінгвосоціокультурна компетентність, філологія, медіація, міжкультурна комунікація.
Summary. The article examines the general contents of the elective educational discipline "Interpreting Poetry". It describes such themes of the course as "poetry in the system of the fine arts", "imagery and symbolism in poetry", "English and Scottish folk ballad". It is noted that works of fiction have a high level of aesthetic, educational and developing potential, and interpretation of the information which they contain stimulates students' analytical thinking, develops their artistic and aesthetic perception, enriches their souls. It is concluded that it is possible to develop students' linguosociocultural competence through interpretation of poetic texts since indirect intercultural communication will broaden students' horizons increasing their linguosociocultural knowledge which is necessary for mutual understanding in intercultural interactions and for the development of their oral or written ability to mediate. It is emphasized that interpretation of poetic texts will promote students' love for and interest in the aesthetics of poetry and philology as a profession.

Key words: poetic text, interpretation, linguosociocultural competence, philology, mediation, intercultural communication.

Мета: представити особливості формування лінгвосоціокультурної компетентності студентів четвертого курсу англійського відділення факультету іноземних мов ДВНЗ "Прикарпатський національний університет імені Василя Сте- фаника" на основі інтерпретації поетичних творів.

Постановка проблеми в загальному вигляді. Фахова підготовка майбутніх учителів англійської мови і перекладачів передбачає формування у них здатності і готовності до професійного міжособистісного спілкування у міжкультурному середовищі. У новому документі Загальноєвропейських Рекомендацій з мовної освіти (CEFR Companion Volume with New Descriptors) наголошується на важливості розвитку здатності до міжкультурної медіації в усній чи письмовій формі, зокрема, формуванні вмінь (пере)формулювати вихідні повідомлення засобами перекладу, інтерпретації, парафразу чи резюме $[15$, c. 32]. Тому сучасна методика навчання іноземних мов і культур акцентує увагу на необхідності розвитку лінгвосоціокультурної компетентності (ЛСКК) студентів [8, с. 92], яка визначається вченими як комплекс специфічних лінгвокраїнознавчих, культурознавчих, соціолінгвістичних, соціально-психологічних та міжкультурних знань, навичок та вмінь, на основі яких формується здатність і готовність особистості до міжкультурної комунікації у ролі ії учасника і посередника $[1$, c. 48]. Поза межами автентичного культурного середовища, мови, що вивчається, важливе значення відіграють автентичні художні твори, які є відображенням лінгвосоціокультурної специфіки іншомовного суспільства та можуть забезпе- 
чити опосередкований діалог культур, ознайомлення з особливостями "чужої" лінгвокультури, ïï соціокультурними кодами, а отже, становлення "вторинної мовної особистості".

Аналіз досліджень і публікацій. Питанню використання творів художньої літератури в методиці навчання іноземних мов присвячено чимало досліджень (Т. Вдовіна, В. Матвейченко, С. Матрон, Л. Новохатько, Г. Подосиннікова, Л. Рудакова, С. Сафарян, О. Сіваченко, Л.Смелякова, Н. Сяська, В. Черниш та ін). Особливості сприйняття художніх творів вивчали: А. Антіпова, Л. Бутакова, Л.Мєтельська, А. Новіков, О. Орлова, Л. Смелякова та інші. У зарубіжній методиці до проблеми застосування художніх творів для розвитку іншомовних умінь прибігали С. Брумфіт (Ch. Brumfit), Дж. Вінстон (J. Winston), Г.Лазар (G. Lazar), М. Шорт (М. Short) та інші. Питання формування ЛСКК вивчалася такими науковцями, як О. Бирюк, М. Дука, І. Голуб, М. Нацюк, Н. Осадча, Н. Сарновська, В. Сафонова. Так, О. Кочукова розробила методику навчання критичного розуміння соціокультурного змісту іншомовних художніх фільмів; Л. Кожедуб довела важливість розвитку вмінь інтерпретації лінгвостилістичних засобів художніх творів для формування німецькомовної компетентності в читанні. Л. Мєтєльська дослідила етнопсихолінгвістичні особливості сприйняття художніх текстів вторинною мовною особистістю. М. Нацюк розробила методику формування ЛСКК у читанні художньої літератури.

Аналіз наукової літератури дозволив зробити висновок про те, що інтерпретація лінгвостилістичних засобів поетичних творів і різноманітних екстралінгвістичних (позамовних) факторів, що пов'язані з ними, сприятиме розвитку ЛСКК студентів.

Виклад основного матеріалу дослідження. Згідно з Програмою з англійської мови для університетів/інститугів однією з основних цілей навчання іноземної мови в закладах вищої освіти $\epsilon$ виховання позитивного ставлення студентів до культури країни, мова якої вивчається [11, 3]. Тому використання автентичних художніх творів у процесі вивчення іноземної мови сприятиме досягненню мети. Читання іншомовних художніх творів - це опосередкована міжкультурна комунікація автора і реципієнта, якій притаманні такіж характеристики, конфлікти і бар'єри, як і безпосередньому міжкультурному спілкуванню [9, с. 152]. Така комунікація передбачає осягнення смислу прочитаного, а результатом смислового сприйняття тексту буде виникнення у свідомості реципієнта "читацької проекції" - когнітивно-емотивної інтерпретації зображеної у тексті предметної ситуації з точки зору носія певної культури [7, с. 34].

Об'єктом нашої уваги стала англомовна поезія. Її реципієнтом виступає вторинна мовна особистість, яку, слідом за Л. Мєтєльською, будемо розуміти як національну (українську) мовну особистість, рівні якої доповнені і збагачені за рахунок присвоєння їм рівнів іншомовної (квазі) мовної особистості, що формуються у процесі оволодіння іноземною мовою під час цілеспрямованого навчання поза межами культурного середовища мови, яка вивчається [7, $c$. 34].

Варто підкреслити, що автентичні художні тексти є складними для осягнення студентами на всіх етапах навчання [12, c. 20]. Оскільки автор та реципієнт належать до різних лінгвокультур, імовірність нерозуміння вторинною мовною особистістю специфічних явищ іншомовної культури, а отже, і смислового сприйняття інокультурних художніх текстів, є високою [7, c. 34]. Тому під час інтерпретації поетичних творів українські студенти стикаються не тільки 3 певними лінгвістичними труднощами, але і з тими, що пов'язані з їх сприйняттям як моделі "чужої" культури [7, c. 34]. Так, формування здатності впізнавати та інтерпретувати культурні, національні і художні коди, що закладені в поетичних текстах, а також перекодовувати їх у власну систему кодів сприятиме розвитку вміння мобілізувати набуті соціокультурні знання для досягнення взаєморозуміння у ситуаціях міжкультурного спілкування.

Інтерпретація художнього тексту $\epsilon$ однією $з$ провідних галузей сучасної філології. Як літературознавці й фольклористи, так і мовознавці ведуть активні пошуки в царині герменевтики авторського і народного словесного твору. Власне і переклад можна розглядати як різновид мистецтва інтерпретації. Він трактує думки і почуття автора художнього твору, створені ним образи і використані засоби увиразнення мовлення за допомогою іншої мови. Інтерпретація прозового, поетичного і драматургічного текстів $є$ своєрідною площиною перетину названих суміжних філологічних наук, що вможливлює доповнення і збагачення одна одної. Студенти кафедри англійської філології факультету іноземних мов ДВНЗ "Прикарпатський національний університет імені Василя Стефаника" мають змогу отримувати глибокі та різнобічні знання під час слухання фундаментальних лекційних курсів з мовознавства, літературознавства і перекладознавства. Здобутий ними інструментарій необхідний як для написання магістерської роботи, так і професійної самореалізації. Випускники - фахівці іноземної філології, майбутні викладачі, перекладачі та науковці матимуть справу 3 мовою і текстом, а також тлумаченням цієї неподільної єдності.

Важливий внесок у фахову підготовку спеціалістів у галузі іноземних мов роблять елективні дисципліни. Вибіркова навчальна дисципліна "Інтерпретація поетичного тексту" (тут і далі "ІПТ" О. К., І. Б.) насамперед органічно пов'язана з наступними: "Зарубіжна література", "Сучасна література країни, мова якої вивчається", "Лінгвостилістичний аналіз та інтерпретація художнього тексту", "Лексикологія", "Стилістика", "Фонетика", "Країнознавство Великої Британії та Північної Ірландії та Сполучених Штатів Америки" тощо.

"IПТ" має на меті вивчення естетики усного та писемного поетичного слова у контексті красних мистецтв, атакож крізь призму світової культури і традицій, навіть більше - прищеплення любові до фаху іноземного філолога. Прослухавши курс, студенти повинні вміти аналізувати формально-змістові особливості поезії (фольклорної та літературної); виокремлювати в літературних творах міфологічні та фольклорні мотиви, художні образи і тропи, прочитувати їх символізм, простежуючи їх актуальність і затребуваність у сучасній літературі та суспільному житті; користуватися англомовною термінологією та знаннями 3 основ версифікації, поціновувати милозвучність і сканувати метричний малюнок поетичного тексту; інтерпретувати культурні, історичні та соціальні феномени, щознайшли відображення у поезії.

Як зазначає I. Кожедуб, художні твори мають високий естетичний, виховний і розвивальний потенціал, тому інтерпретація таких текстів стимулюватиме аналітичне мислення студентів, розвиватиме їх естетичну потребу та сприятиме розв'язанню проблем виховання особистостей, збагачуючи їх духовний світ [5, c. 10].

Прикметно, що матеріалом дисципліни "ІПТ" слугують ілюстрації і приклади з греко-римської міфології, британської та американської фольклорної і професійної поезії та прози. Водночас навчальний курс використовує такий принцип співвивчення мови і культури, як принцип діалогу культур, адже проводить паралелі до української культури, 
літератури і фольклору. "Будування мостів" між двома генеалогічно дистантними культурами, а саме германською $\mathrm{i}$ слов'янською, вияскравлює самобугність івиявляє схожості між британським і українським, а разом із тим і американським словесними мистецтвами.

Так, студіювання першої теми елективної дисципліни, присвяченої інтерпретації поетичного тексту, "Поезія у колі красних мистецтв" базується на класифікації мистецтв, яку розробив німецький філософ Г.-Е. Лессінг [6], та передбачає аналіз грецького міфа про Орфея та Еврідіку. Художнє відображення названого міфу у так званих "просторових" видах мистецтва, зокрема у скульптурі та живописі, а згодом у "часових" - музиці і словесній творчості, дає можливість підкреслити обмеженість і спроможність названих мистецтв у відтворенні мотивів одного і того самого сюжету.

Простеження літературно-фольклорної еволюції художнього бачення Орфея протягом останніх двох тисячоліть демонструє негаснучу актуальність ідейно-змістового наповнення міфу, можливості багатогранної його модернізації та зміну світоглядних уявлень і настроїв самого суспільства. Орфей уособлює собою архетип поета i музиканта, творчості й гармонії. Ознайомлення студентів зі своєрідними, іноді радикальними відхиленнями від класичного сюжету сприятимуть розвиткові вмінь їх критичного мислення та говоріння, зокрема, умінь тлумачити, коментувати та аналізувати якомога більший обсяг інформації, закладений у творах, робити висновки, виводити судження, пояснювати свою думку, визначати і трактувати екстралінгвістичні компоненти твору на основі розгляду мовних засобів, оперувати літературознавчими, лінгвостилістичними, естетичними та соціокультурними знаннями, а також виявляти та досліджувати інтертекстуальні зв'язки у творах.

Цікаво порівняти і здебільшого традиційно позитивне ставлення до постаті та вчинків греко-римського героя ("King Orfeo" (Чайлд № 19 А) [20]), "Орфеєве чудо" (1913) Лесі Українки), і цілком негативне (травестії неокласичної літератури Англії (1660-1785), "Eurydice" (1973-1974) Рейчел Бло ДюПлессі), і атрибуцію назагал позитивного героя певними вадами ("The Medusa Frequency" (1987) Р. Гобана [18], "Видіння Орфея" (2016) Галини Пагутяк [10]) тощо. Окрім того, студентам пропонується перевтілитися у письменників та створити власні художні реінтерпретації міфу про Орфея та Еврідіку у вигляді есе, що сприя- тиме розвитку вмінь творчого переосмислення творів та вдосконаленню їхніх умінь у письмі.

Поняттю "образ" у ширшому значенні, що є основною формою представлення інформації у мистецтві, та "поетичний образ", "мікрообраз" і "макрообраз" у вужчому сенсі, а також його символічному навантаженню присвячено другу тему дисципліни "IПТ". Вивчення класифікації поетичних образів за конкретно-чугтєвим сприйняттям дійсності, візуалізація віршових фрагментів відповідними картинами чи супровід музичнопісенними записами сприяють не лише кращому запам'ятовуванню теоретичного матеріалу, а й розвиває уяву, фантазію і креативність у слухача курсу.

Яскравою ілюстрацією сконденсованих поетичних символів слугують орнітоморфні образи. Їх вивчення починається з поезії (авторської та фольклорної), проте відбувається у контексті звичаїв i традицій, уявлень і вірувань, притаманних для етнічних культур Сполученого Королівства, США та України, міфології, а також історіїі геральдики Британії, крилатих висловів і паремій тощо. Так, образ альбатроса з поеми Семюела Тейлора Колріджа "The Rime of the Ancient Mariner: in Seven Parts" (1798, перегл. 1817) належить до найвідоміших в англійській та світовій літературах [див. 47.

У розповіді про співпрацю молодих двадцятип'ятилітніх С. Колріджа і В. Вордсворта над першим виданням названого та інших поетичних творів у збірці "Lyrical Ballads" (1798) варто згадати i про географію південного заходу Англії, і про окремі факти з біографії цих засновників англійського романтизму. Дружба і спільні довготривалі прогулянки серед Квантокських пагорбів у графстві Сомерсет аж до берегів Брістольської затоки, краса природних ландшафтів надихали поетів на творчість. Зараз туристи можуть повторити спеціально облаштований маршрут "the Coleridge Way" піших прогулянок двохсотлітньої давності, а також завітати до колишніх помешкань, а тепер музеїв C. Колріджа та В. і Д. Вордсвортів. Як наслідок, ця територія $\epsilon$ не лише цінною перлиною природи, а й несе безумовну історико-культурну пам'ять для англійців, перебуває під захистом Ексмурського національного парку [16].

Про значущість вкладу С. Колріджа в англійську мову, літературу і культуру та актуальність поеми "The Rime of the Ancient Mariner..." (1798, перегл. 1817) свідчать, зокрема, поетичні цитати, які завдяки своїй влучності стали за- гальновживаними і збагатили словник англійської мови ("an albatross (around your neck)" [13, c. 35]). А статуя Старого Мореплавця з альбатросом височіє на березі Брістольської затоки [21] та увіковічує двох головних персонажів цього поетичного шедевра англійського поета у скульптурі.

Логічним $є$ зосередження "IПТ" на вивченні англо-шотландської фольклорної балади. Як відомо, усна література передувала появі писемної словесності. На сучасному етапі відбувається як паралельний окремішній розвиток народної і літературної поезії та прози, так і їх синкретизм, що виявляє себе у цікавих явищах фольклоризації творів літературного походження та фольклоризму в літературній творчості.

Фольклор - одна з підвалин культури і світогляду германських народів. "Починаючи з другої половини XVIII ст. одним із найбільш репрезентативних жанрів народної традиції Великобританії стала балада, яка здобула велику популярність у США та Свропі, зокрема і в Україні, до певної міри вплинувши на шлях розвитку літератури і науки. Сконденсований та розмальований готичними фарбами універсум фольклорної балади дозволяє збагнути багатоманітність середньовічного життя переважно британської аристократії з його універсальними й водночас неповторними реаліями, прагненнями і викликами, правилами і канонами, вірою у надприродне i фантастичне" [19, c. 4].

Прочитання та аналіз англо-шотландських історичних балад ознайомлює не лише з особливостями фольклорно-поетичного відображення теми війни і іiі трагізму, а й танцювальним мистецтвом Англії, поглиблює знання з історії формування британської державності та її геральдичних символів тощо. Так, англошотландська історична балада "The Rose of England" (Чайлд № 166) [22] в алегоричній формі віддзеркалює битву при Босворті (Bosworth, тепер Market Bosworth), що відбулася 22 серпня 1485 року на землях графства Лестершир.

Художня вартісність балади "Тhe Rose of England" (Чайлд № 166), у часі іii студіювання створює чудові передумови для засвоєння, серед іншого, азів геральдики Британії. Тут діючими особами виступають фітоморфні та зооморфні образи, які зображені на гербах відомих родів Сполученого Королівства.

А щодо важливості історико-суспільного контексту, то битва при Босворті, яка стала фінальним і вирішальним акордом увійськовому протистоянні Білої та Червоної троянд (1455-1487) за королі- 
вський престол Англії, дала поштовх для створення балади "The Rose of England" (Чайлд № 166). Після поразки короля Англії Річарда III граф Річмонд посів трон під іменем Генріх VII та поклав початок шляхетному дому Тюдорів.

Батальна ж пісня англо-шотландського Помежів'я "Flodden Field" (Чайлд № 168) присвячена одній з найважливіших битв між Шотландією та Англією в історії Великобританії. 9 вересня 1513 року напагорбах Флоддену неподалік від селища Бренкстон, що у графстві Нортумберленд, відбулося зіткнення військ Шотландії та Англії, що призвело до поразки Шотландії, загибелі 10000 шотландців і їхнього короля Якова IV (14731513). 4000 англійських солдат поклали своєжиттязаради перемогиАнглії [див. 3]. У передостанньому рядку останньої дванадцятої строфи тексту увагу привертає згадка про англійський народний танець "morrice-dance" [17, c. 353] шотландського короля Якова IV.

На початку XX ст. активно досліджував та збирав англійські народні танці англійський музикант і фольклорист Сесіл Джеймс Шарп (1859-1924). У 2014 p. С. Дж. Шарп став першою особою, котру посмертно відзначили за значний внесок у світ фольклорної музики, а також вшанували виконанням "Cotswold morris" у створеній того року номінації "The Hall of Fame" щорічної премії "ВВC Radio 2 Folk Awards" [14]. Цей відеозапис ліг в основу творчої обробки англійського традиційного танцю, яку здійснили та продемонстрували студенти факультету іноземних мов ПНУ імені Василя Стефаника в рамках флешмобу "Танці народів світу" у 2018 р. [2].

Вважаємо, що здобуті лінгвосоціокультурні знання студенти зможуть використовувати для розуміння та інтерпретації різноманітних автентичних повідомлень під час безпосереднього чи опосередкованого міжкультурного спілкування. Однак, як зазначається М. Нацюк, для успішного оволодіння студентами ЛСКК з використанням творів художньої літератури необхідно акцентувати увагу на культурній обумовленості їх сприйняття та існуванні різних поглядів; розвивати толерантність до "іншості"; навчати долати власні стереотипи і прояви етноцентризму; навчати оцінювати текст з позицій різних культур; розвивати вміння сприймати художні твори на основі емпатії [9, c. 155].

Висновки та перспективи подальших досліджень. Таким чином, у процесі засвоєння елективної дисципліни "IПТ" студенти формують навички i вміння з інтерпретації поетичних текстів, а також удосконалюють іншомовні компетентності в говорінні, читанні, письмі й аудіюванні. Водночас поглиблюється i їхня іншомовна лінгвосоціокультурна компетентність. Студенти отримують знання про становлення та розвиток етносів і державності Сполученого Королівства, основні історичні події, географію, мистецтво, фольклор, прийняті у країні символи, крилаті вислови тощо. А застосування принципу діалогу культур уможливлює пізнання і співвіднесення матеріальних та духовних досягнень в англомовній (Велика Британія, США) та українській культурах. Усе це сприяє вихованню у молоді любові та інтересу до естетики художнього слова, фаху філолога.

Перспективним напрямом подальших наукових досліджень може стати розробка методики формування умінь інтерпретації творів красного письменства засобами їх художнього перекладу.

\section{ЛІТЕРАТУРА}

1. Задорожна I. П. Теоретико-методичні засади організації самостійної роботи майбутніх учителів 3 оволодіння англомовною комунікативною компетенцією: дис. ... д-ра пед. наук: 13.00.02 / Київський нац. лінгв. ун-т. Київ, 2012. $770 \mathrm{c}$.

2. Канал 402. Студенти ПНУ просто неба влаштували танцювальне шоу. YouTube. URL: https:// www.youtube.com/watch? $=$ ZXpnJyYoK4 (дата звернення: 27.02.2019).

3. Карбашевська О. В. Історична балада: українсько-британський контекст. Іноземна філологія: укр. наук. зб. Львів: ЛНУ імені Івана Франка, 2015. Вип. 128. C. $253-260$.

4. Карбашевська О. В. Фольклорнолітературна взаємодія у творчості поетів-романтиків: українсько-британський контекст. Мова і культура: наук. журнал. Київ: Видав. дім Дмитра Бураго, 2014. Вип. 17. Т. VII (175). С. 326334.

5. Кожедуб Л. Г. Формування у майбутніх філологів німецькомовної компетенції в читанні на основі інтерпретації художніх текстів: дис. ... канд. пед. наук: 13.00.02 / Київський нац. лінгв. ун-т. Київ, $2010.305 \mathrm{c}$.

6. Лессінг Г.-Е. Лаокоон, або Про межі живопису і поезії. Мінна фон Барнгельм. Емілія Галотті. Лаокоон: п'єси, трактат / пер. 3 нім. Б. Гавришкова і Е. Поповича. Київ: Вид-во худ. літ. "Дніпро", 1976. Серія "Вершини світового письменства". T. 21. C. 169-315.

7. Метельская Л. Н. Этнопсихолинг- вистические особенности восприятия художественного текста на иностранном языке. Филологические науки в МГИ$M O$ : Сборник научных трудов. Москва: МГИМО-Университет, 2008. № 33 (48). C. $34-40$.

8. Методика навчання іноземних мов і культур: теорія і практика: підручник для студентів класичних, педагогічних i лінгвістичних університетів / Бігич О. Б. та ін.; за заг. ред. С. Ю. Ніколаєвої. Київ: Ленвіт, 2013. 590 с.

9. Нацюк М. Б. Психолінгвістичні передумови формування лінгвосоціокультурної компетентності у майбутніх учителів іноземної мови в процесі читання художньої літератури. Вісник Житомирського державного університету. Педагогічні науки. 2013. № 67. С. 151156.

10. Пагутяк Г. Видіння Орфея. Захід сонця в Урожі. Книга вершинна: романи, повісті, новели та оповідання. Вид. 3тє, допов. Львів: ЛА "Піраміда", 2016. C. 244-250.

11. Програма з англійської мови для університетів / інститутів (п'ятирічний курс навчання): проект / Ніколаєва С. Ю. та ін.; під кер. С. Ю. Ніколаєвої, М. І. Солов'я. Вінниця: Вид-во "Нова книга", $2001.245 \mathrm{c}$.

12. Соломонова А. А. Лингводидактическое описание ключевых компетенций иностранного студента-филолога: автореф. дис. ...канд. пед. наук: 13.00.02. Москва, 2010.24 с.

13. Albatross. Longman Exams Dictionary. Pearson Education Limited, 2006. P. 35.

14. BBC Radio 2. A Tribute To Cecil Sharp at the Folk Awards 2014. YouTube. URL: https://www.youtube.com/ watch? $=\mathrm{uYgc5}$ yBGOfw (Last accessed: 27.02.2019).

15. Common European Framework of Reference for Languages: Learning, Teaching, Assessment. Companion Volume with New Descriptors. Council of Europe. 2017. URL: https://rm.coe.int/cefrcompanion-volume-with-new-descriptors2018/1680787989 (Last accessed: 27.02.2019).

16. ExmoorNP. The Coleridge Way - in the footsteps of the Romantic Poets. YouTube. URL: https:// w w w . y o u t u b e c c o m / watch?time_continue $=274 \& v=p Z A R g L s U L 5 c$ (Last accessed: 27.02.2019).

17. Flodden Field. The English and Scottish Popular Ballads: In 5 v. / edited by Francis James Child. Reprint edition. Boston and New York: Houghton, Mifflin and Company, 1898. V. III. P. II. P. 351353. 
18. Hoban R. The Medusa Frequency. New York : The Atlantic Monthly Press, 1987. 143 p.

19. Karbashevska Oksana. Передмова. Interpreting Poetry: English and Scottish Folk Ballads. A manual for students (Year V, speciality "Language and Literature (English)"). Ivano-Frankivsk : NAIR, 2015. P. 4.

20. King Orfeo. The English and Scottish Popular Ballads: In 5 v. / edited by Francis James Child. Reprint edition. Boston and New York: Houghton, Mifflin and Company, 1898. V. I. P. I. 1898. P. 217.

21. Rime of the Ancient Mariner (The). Wikipedia, the Free Encyclopedia. URL: https://en.wikipedia.org/wiki/ The_Rime_of the_Ancient_Mariner(Last accessed: 27.02.2019).

22. Rose of England (The). The English and Scottish Popular Ballads: in 5 v. / edited by Francis James Child. Reprint edition. Boston and New York : Houghton, Mifflin and Company, 1898. V. III. P. II. 1898. P. 331-333.

\section{REFERENCES}

1. Zadorozhna I. P. Teoretykometodychni zasady orhanizatsii samostiinoi roboty maibutnikh uchyteliv z ovolodinnia anhlomovnoiu komunikatyvnoiu kompetentsiieiu: dys. ...d-ra ped. nauk: 13.00.02 / Kyivskyi nats. linhv. un-t. Kyiv, $2012.770 \mathrm{~s}$.

2. Kanal 402. Studenty PNU prosto neba vlashtuvaly tantsiuvalne shou. YouTube. URL : https:// www.youtube.com/watch?v=ZXpnJyYoK4 (data zvernennia: 27.02.2019).

3. Karbashevska O. V. Istorychna balada: ukrainsko-brytanskyi kontekst. Inozemna filolohiia: ukr. nauk. zb. Lviv: LNU imeni Ivana Franka, 2015. Vyp. 128. S. 253-260.

4. Karbashevska O. V. Folklornoliteraturna vzaiemodiia u tvorchosti poetivromantykiv: ukrainsko-brytanskyi kontekst. Mova i kultura Naukovyi zhurnal. Kyiv: Vydavnychyi dim Dmytra Buraho, 2014. Vyp. 17. T. VII (175). S. 326-334.

5. Kozhedub L. H. Formuvannia u maibutnikh filolohiv nimetskomovnoi kompetentsii v chytanni na osnovi interpretatsii khudozhnikh tekstiv: dys. ...kand. ped. nauk: 13.00.02 / Kyivskyi nats. linhv. un-t. Kyiv, 2010.305 s.

6. Lessing G.-E. Laokoon, abo Pro mezhi zhyvopysu i poezii. Minna fon Barnhelm. Emiliia Halotti. Laokoon : piesy, traktat / per. z nim. B. Havryshkova i E. Popovycha. Kyiv : Vyd-vo khud. lit. "Dnipro", 1976. Seriia "Vershyny svitovoho pysmenstva". Tom 21. S. 169315.

7. Metelskaia L. N. Etnopsikholinhvisticheskiie osobennosti vospriiatiia khudozhestvennoho teksta na inostrannom yazyke. Filolohicheskiie nauki v MHIMO: Sbornik nauchnykh trudov. Moskva : MHIMO-Universitet, 2008. № 33 (48). S. $34-40$.

8. Metodyka navchannia inozemnykh movi kultur: teoriia i praktyka: pidruchnyk dlia studentiv klasychnykh, pedahohichnykh i linhvistychnykh universytetiv/ Bihych O. B. ta in.; za zah. red. S. Yu. Nikolaievoi. Kyiv : Lenvit, 2013. $590 \mathrm{~s}$.

9. Natsiuk M. B. Psykholinhvistychni peredumovy formuvannia linhvosotsiokulturnoi kompetentnosti u maibutnikh uchyteliv inozemnoi movy $\mathrm{v}$ protsesi chytannia khudozhnoi literatury. Visnyk Zhytomyrskoho derzhavnoho universytetu. Pedahohichni nauky. 2013. № 67. S. 151-156.

10. Pahutiak H. Vydinnia Orfeia. Zakhid sontsia v Urozhi. Knyha vershynna: Romany, povisti, novely ta opovidannia. Vyd. 3-tie, dopov. Lviv : LA "Piramida", 2016. S. 244-250.

11. Prohrama $z$ anhliiskoi movy dlia universytetiv / instytutiv (piatyrichnyi kurs navchannia): Proekt/S. Yu. Nikolaieva ta in.; pid ker. S. Yu. Nikolaievoi, M. I. Solovia. Vinnytsia : Vyd-vo "Nova knyha", 2001. $245 \mathrm{~s}$.

12. Solomonova A. A. Linhvodidakticheskoe opisaniie kliuchevykh kompetentsyi inostrannoho studenta-fyloloha: avtoref. dis. ... kand. ped. nauk: 13.00.02 / Hos. un-t rus. yaz. im. A. S. Pushkina. Moskva, 2010.24 s.

13. Albatross. Longman Exams Dictionary. Pearson Education Limited,
2006. P. 35.

14. BBC Radio 2. A Tribute To Cecil Sharp at the Folk Awards 2014. YouTube. URL: https://www.youtube.com/ watch? $\mathrm{v}=\mathrm{uYgc5}$ yBGOfw (Last accessed: 27.02.2019).

15. Common European Framework of Reference for Languages: Learning, Teaching, Assessment. Companion Volume with New Descriptors. Council of Europe. 2017. URL: https://rm.coe.int/cefrcompanion-volume-with-new-descriptors2018/1680787989 (Last accessed: 27.02.2019).

16. ExmoorNP. The Coleridge Way in the footsteps of the Romantic Poets. YouTube. URL: https:// w w w y o u t u b e . c o m / watch?time_continue $=274 \& \mathrm{v}=\mathrm{pZARgLsUL5c}$ (Last accessed: 27.02.2019).

17. Flodden Field. The English and Scottish Popular Ballads: In 5 v. / edited by Francis James Child. Reprint edition. Boston and New York: Houghton, Mifflin and Company, 1898. V. III. P. II. P. $351 ? 353$.

18. Hoban R. The Medusa Frequency. New York: The Atlantic Monthly Press, 1987. 143 p.

19. Karbashevska O. V. Peredmova. Interpreting Poetry: English and Scottish Folk Ballads. A manual for students (Year $\mathrm{V}$, speciality "Language and Literature (English)"). Ivano-Frankivsk : NAIR, 2015. P. 4.

20. King Orfeo. The English and Scottish Popular Ballads: in 5 v. / edited by Francis James Child. Reprint edition. Boston and New York: Houghton, Mifflin and Company, 1898. V. I. P. I. 1898. P. 217.

21. Rime of the Ancient Mariner (The). Wikipedia, the Free Encyclopedia. URL: https://en.wikipedia.org/wiki/ The_Rime_of_the_Ancient_Mariner(Last accessed: $\overline{27} \cdot \overline{02} \cdot 2019$ ).

22. Rose of England (The). The English and Scottish Popular Ballads: in 5 v. / edited by Francis James Child. Reprint edition. Boston and New York: Houghton, Mifflin and Company, 1898. V. III. P. II. 1898. P. 331-333.

Стаття надійшла 9.04.2019 p. 